\title{
Insect Management in Pecans 1
}

Russell F. Mizell, III

Disease and insects are often the limiting factors in the production of pecans in Florida. The crop requires about 7 months to develop and during that time is subject to attack by a variety of pests. A good disease and insect control program is important, not only in protecting the maturing crop, but it is essential to the production of high yields year after year. Trees, which are prematurely defoliated by insects, mites, and diseases, frequently produce nuts of low quality and set a light crop the following year. Pecan varieties differ in resistance to scab and other diseases. Scab susceptible varieties will require more fungicide sprays than resistant varieties. Check with your county extension director to determine the most suitable varieties for local conditions. Although today's pecan grower is fortunate to have effective fungicides, insecticides, and improved spray equipment available to him, spraying for pest control is not an easy job. It requires attention to many details that on the surface may seem unimportant. Even the best spray program can be improved if the following cultural and sanitary practices are followed:
1. Provide better air circulation in orchard; mow or disc weeds, and prune low hanging limbs. Keeping the tree row weed-free by use of herbicides is recommended.

2. Maintain tree vigor by following recommended fertility practices. (See Circular 280-B, Pecan Production in Florida.)

Perhaps the three most important factors in a spray program are timing, coverage and rate (discussed in subsequent sections).

\section{Timing}

Some insects such as pecan phylloxera, nut casebearer, pecan weevil and hickory shuckworm occur in orchards at particular and somewhat predictable times (Figure 1). Timing of sprays for control of these insects is very important and each grower should learn to recognize the vulnerable stages of these insects and time sprays accordingly. Remember that about $75 \%$ of nuts abort naturally from the tree. If pests such as phylloxera occurred last year, control may be necessary this year. Apply control for leaf phylloxera when the new growth is

1. This document is Fact Sheet ENY-806 (IG077), one of a series of the Entomology and Nematology Department, Florida Cooperative Extension Service, Institute of Food and Agricultural Sciences, University of Florida. First printed: October 1993. Revised: May 2009. Please visit the EDIS Website at http://edis.ifas.ufl.edu.

2. Russell F. Mizell, III, professor, Entomology and Nematology Department, Cooperative Extension Service, Institute of Food and Agricultural Sciences, North Florida Research and Education Center, University of Florida, Quincy, FL 32351.

The use of trade names in this publication is solely for the purpose of providing specific information. UF/IFAS does not guarantee or warranty the products named, and references to them in this publication does not signify our approval to the exclusion of other products of suitable composition. Use pesticides safely. Read and follow directions on the manufacturer's label.

The Institute of Food and Agricultural Sciences (IFAS) is an Equal Opportunity Institution authorized to provide research, educational information and other services only to individuals and institutions that function with non-discrimination with respect to race, creed, color, religion, age, disability, sex, sexual orientation, marital status, national origin, political opinions or affiliations. U.S. Department of Agriculture, Cooperative Extension Service, University of Florida, IFAS, Florida A. \& M. University Cooperative Extension Program, and Boards of County Commissioners Cooperating. Millie Ferrer, Interim Dean 
about $1 / 2$ inch in length. Nut casebearer sprays should be timed to control first generation larvae before they enter the nuts. Use the new phermone traps to monitor for adult nut casebearers emergence and population density. Nut casebearer populations differ from orchard to orchard and year to year. Scout for eggs on the small nuts after pollination. Controls should be applied 14 - 21 days after first male is captured in the traps.
Growers should monitor for adult weevils starting about July 15 using the Tedders or Circle traps. Contact your county agent for more information. Homeowners can also use these traps to suppress damage from pecan weevils.

Spray when adult weevils are found and continue at 7 to 10 day intervals during weevil emergence. Spraying need not start until the shell begins to

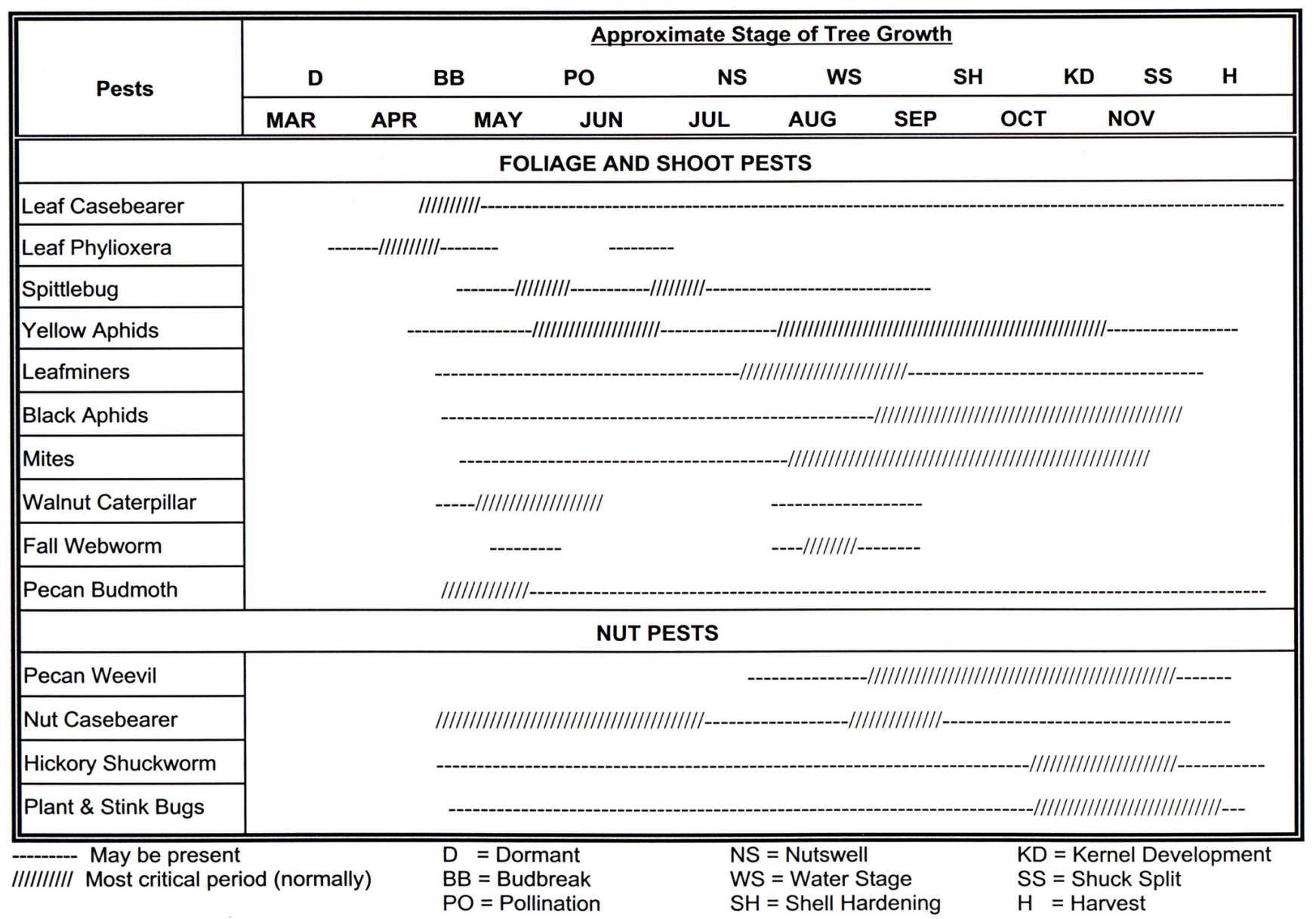

Figure 1. Phenology or seasonal occurrence of pecan arthropod pests.

The pecan weevil can be a serious pest of pecans in Florida. The adults emerge from the soil beginning in July and can continue emergence into November. Adults feed on the nuts until the shell begins to harden and then they begin laying eggs. Feeding prior to shell hardening prevents nut development and causes the nut to drop. harden, if the early population does not appear large enough to cause serious nut drop. Drought periods will delay weevil emergence.

Pecan aphids have two population peaks: one in May - June and a larger one in August - October. Winter cover crops of hairy vetch with crimson clover planted in row middles are recommended to augment beneficials. In most years beneficials will 
build up in the cover crops in February - April and then suppress the May - June aphid populations in pecan. A newly introduced lady beetle, Harmonia axyridis, is an important biological control of pecan aphids. It is suggested that pyrethroids not be used alone or in combination in early or mid season and further do not use more than 2 applications per season.

Excessive use of insecticides should be avoided as it may create insect problems that otherwise would not exist, as well as adding to environmental pollution.

\section{Coverage}

In applying spray materials, all leaves, twigs, and nuts should be covered. Hydraulic machines are designed to use large volumes of water to carry the chemicals to the trees. Sprays should be applied until water runs off leaves in the upper portion of the tree. Do not attempt to concentrate or use low volume sprays with hydraulic equipment.

Air blast and mist blowers are designed for low volume applications. Air blast equipment should be adjusted before the spray season begins to deliver the desired volume of spray in the proper pattern as is dictated by tree size. Consult instruction manuals or spray machine representative for advice on correct placement of spray nozzles.

Remember, when spraying with air blast sprayers, the pesticide is carried to the tree in a small volume of water which is diluted by a larger volume of air. Too fast a rate of travel will result in insufficient coverage where the trees are not filled with spray-laden air; thus poor coverage results.

\section{Rates}

Insecticides are recommended at specific rates of application which have been found to be effective and non-phytotoxic (Table 1). It is, therefore, very important to: 1) know the required rate of chemical per tree; 2) calculate the gallons of spray per tree the machine will deliver at a given rate of travel; 3 ) calculate the amount of chemical to add per tank. Example: Carbaryl is recommended at 0.30 pound of $80 \%$ formulation per tree. If 10 trees were sprayed per 100 gallons of water, then 10 times 0.30 equals 3.0 pounds of carbaryl required for 100 gallons or 15 pounds per 500 gallon tank.

The insecticides listed in this guide have been shown in field trials to be effective against the pests. Because of local differences in use patterns, (i.e. frequency of application, pesticides used, etc.), some materials may no longer be effective or they may cause outbreaks of other pests. Alternating materials should help to avoid or delay these problems as will the practice of spraying only when necessary. In any event, the grower should be aware of this and be prepared to shift materials as the situation demands.

\section{Precautions}

Some pesticides are especially toxic to man and should be applied only by state licensed applicators. Read the entire label before opening any pesticide container and heed all cautions and warnings. Store pesticides in original labeled containers and out of reach of children, pets, and livestock, under lock and key. Dispose of left-over spray materials and all empty containers promptly and safely. Follow the recommended dosage and waiting periods to avoid excess residues and injury to plants and animals. Avoid drift of pesticides to adjacent areas.

\section{Suggested Control Program}

This schedule is a guide to aid the grower; however, all pertinent information relating to the pesticides cannot be included. Many of these sprays can be eliminated by monitoring for the presence of target pests. It is the responsibility of the grower to read the label for information on restrictions and correct use. Use of a pesticide inconsistent with the label is illegal.

If different pesticide formulations are used, they should be used at an equivalent amount of actual toxicant per acre. Tank mixes of different compounds should be tested in small amounts before filling tank.

\section{Additional Remarks}

Fire ants can disrupt aphid control if not kept out of pecan trees. Chlorpyrifos $4 \mathrm{E}$ at $2 \mathrm{pts} / \mathrm{A}$ is labeled as a ground spray to control fire ants. Chlorpyrifos is also effective as a trunk spray. 
Table 1. Pecan Spray Schedule

\begin{tabular}{|c|c|c|}
\hline Time of Spray & Pesticide & To Control \\
\hline $\begin{array}{l}\text { First } \\
\text { Pre-pollination } \\
\text { (approx. April 1) }\end{array}$ & $\begin{array}{l}\text { Thiodan 50WP, Phaser, Lorsban 4E, Provado 1.6F, } \\
\text { Spintor 2SC, Thionex, Warrior }\end{array}$ & Leaf Casebearer, Phylloxera \\
\hline $\begin{array}{l}\text { Second } \\
\text { Pre-pollination } \\
\text { (approx. April 15) }\end{array}$ & $\begin{array}{l}\text { Bacillus thuringiensis, Confirm } 2 \mathrm{~F} \text {, Guthion } 25 \text { or } 2 \mathrm{~L} \text {, } \\
\text { Imidan, Thionex } \\
\text { Lorsban } 4 \mathrm{E} \text {, Provado } 1.6 \mathrm{~F} \text {, Thionex }\end{array}$ & $\begin{array}{l}\text { Fall Webworm/Walnut Caterpillar, Nut } \\
\text { Casebearer } \\
\text { Phylloxera }\end{array}$ \\
\hline
\end{tabular}

Remarks: Increase volume per tree as foliage grows. Alternation of insecticide throughout season is suggested to avoid outbreak of secondary pests. Use new nut casebearer phermone traps to monitor adult emergence.

\begin{tabular}{lll}
\hline First cover & Bacillus thuringiensis & Fall Webworm/Other Caterpillars \\
(approx. May 1) & Ammo 2.5E, Asana XL 0.66EC, Brigade, & Aphids, Mavrik only on non-bearing \\
& Dimethoate, Lorsban 4E, Mustang Max, Provado & trees \\
& 1.6F, Thionex & \\
& Acramite, Dicofol 4E, Hexygon, Kelthane MF, & Mites \\
& Savey, Vendex 50WP, Zeal & \\
& Centric, Guthion 50WP, Lorsban 4E, Phaser, & Spittlebugs \\
& Provado 1.6F, Thionex, Warrior &
\end{tabular}

Remarks: Spray for aphids and mites only if numbers avg. more than 50 per compound leaf, if sprayed previously for nut casebearer, do not repeat. Spittlebugs may occur on terminals or nut clusters. Pyrethroids should be used only in combination with Lorsban 4E. Use not more than 2 applications of a pyrethroid.
Second cover
See first cover.
Aphid, Mites, Spittlebug

(approx. May 21)

Remarks: Combinations of insecticides tank mixed may be necessary to control all pests present.

$\begin{array}{lll}\text { Third cover } & \text { See first cover. Mites }\end{array}$

(approx. June 15)

Remarks: Check nuts for shuckworm damage. Spray either Lorsban 4E, Confirm, Guthion 50WP, Imidan 50WP, Cymbush 3E, or Ammo 2.5 EC if present. Confirm has least effects on beneficials.

\begin{tabular}{|lll}
\hline Fourth cover & See first cover. & Aphid, Mites \\
(approx. July 7) & Ammo 2.5E, Asana XL 0.66EC, Confirm 2F, Guthion & Hickory Shuckworm \\
& 25 or 2L, Imidan 70WP, Lorsban 4E, Mustang Max, & \\
& Spintor 2SC, Warrior & Weevil \\
& Carbaryl, Sevin 80S & Fall Webworm/Walnut Caterpillar \\
& Bacillus thuringiensis, Malathion 25WP
\end{tabular}

Remarks: Apply second and third shuckworm spray at 2 wk intervals after first spray. Methomyl is effective against low weevil populations only.

Fifth cover (approx. See fourth cover. Aphid, Mites, Hickory Shuckworm,

July 30) Weevil

Remarks: Aphids and mites may build up if Sevin is used for weevils. Monitor and spray if numbers of aphids exceeds avg. of 30 per compound leaf. Sample randomly throughout the orchard.

$\begin{array}{lll}\text { Sixth cover } & \text { See fourth cover. } & \text { Mites, Aphid, Hickory Shuckworm, } \\ \text { (approx. Aug. 15) } & & \text { Weevil }\end{array}$

Remarks: Aphids and mites should be controlled (less than 30 per compound leaf) as necessary in late season. Foliage should remain on trees until frost. Follow preharvest intervals as indicated by label for specific pesticides. Only products containing carbaryl will provide adequate control of pecan weevil when high populations are present. Carbaryl will eliminate most beneficials and may cause outbreaks of aphids or mites.

Seventh cover $\quad$ Ammo, Centric, Imidan 70WSP, Provado, Warrior $\quad$ Plant and Stink Bugs (approx.

Aug.-harvest)

Remarks: Plant and stink bugs can enter the orchard and begin feeding on nuts at anytime. Drought conditions in late season may lead to stink bug population buildup. Spray when 1 stink bug is found per 40 terminals. 